\title{
ANALISIS PENGGUNAAN SIMULASI INTERAKTIF DALAM PEMBELAJARAN PADA TOPIK HUKUM COULOMB
}

\author{
A. Sadidah ${ }^{1 *}$, A.I. Irvani ${ }^{2}$ \\ ${ }^{1}$ SMP Negeri 1 Cisurupan - Garut \\ Jl. Raya Cisurupan No. 154, Cisurupan, Garut. \\ ${ }^{2}$ Program Studi Pendidikan Fisika, Fakultas Pendidikan Islam dan Keguruan \\ Universitas Garut \\ e-mail: aisadidah@gmail.com
}

\begin{abstract}
Abstrak
Artikel ini bertujuan untuk menjelaskan penggunaan PhET Interactive Simulations sebagai pendukung maupun penganti laboratorium real dalam pembelajaran IPA materi pokok Hukum Coulomb. Analisis data dilakukan dengan metode deskriptif kualitatif. Berdasarkan hasil analisis diperoleh kesimpulan bahwa penggunaan simulasi interaktif dalam pembelajaran pada topik Hukum Coulomb memberikan respons positif siswa dalam menemukan hubungan faktor-faktor yang mempengaruhi gaya Coulomb, respons baik dalam antusiasme pembelajaran dan kemampuan pemecahan masalah peserta didik, karena simulasi interaktif dapat menjelaskan konsep yang abstrak dan dalam penggunaannya tidak memerlukan waktu yang banyak.
\end{abstract}

Kata kunci: Hukum Coulomb, Pembelajaran IPA, PhET, Simulasi Interaktif

\section{Pendahuluan}

Salah satu cabang Ilmu Pengetahuan Alam (IPA) yang dipelajari di tingkat Sekolah Menengah Pertama (SMP) adalah Fisika. Beberapa konsep dalam Fisika termasuk konsep abstrak. Karakteristik beberapa konsep yang abstrak dalam Fisika, menyebabkan adanya kesulitan tersendiri dalam visualisasi dan penyampaiannya kepada peserta didik. Konsep abstrak merupakan konsep yang sulit divisualisasikan atau ditampilkan prosesnya secara langsung melalui kegiatan laboratorium nyata sekalipun. Hal ini kemudian berimplikasi pada rendahnya penguasaan konsep dan perolehan hasil belajar peserta didik.

Pembelajaran yang masih kurang menekankan peran aktif peserta didik merupakan salah satu faktor yang menjadi penyebab kesulitan peserta didik dalam memahami materi Fisika. Pembelajaran seharusnya mampu menciptakan lingkungan yang dapat membantu peserta didik memahami konsep dan proses sains. Hal ini terkait dengan IPA sendiri yang dimaknai sebagai proses meliputi keterampilan proses dan sikap ilmiah yang diperlukan untuk memperoleh dan mengembangkan pengetahuan. Keterampilan proses sains adalah keterampilan yang digunakan peserta didik untuk menyelidiki dunia di sekitar mereka dan untuk membangun konsep ilmu pengetahuan, sedangkan sikap ilmiah adalah bagaimana para ilmuwan bersikap ketika melakukan proses dalam mendapatkan ilmu pengetahuan tersebut (Zubaidah, 2018: 3).

Pembelajaran Fisika selama ini dianggap tidak menarik karena hanya menekankan pada rumus-rumus matematik saja, sehingga untuk mengatasi permasalahan tersebut perlu dibuatkan media pembelajaran Fisika 
yang dapat memudahkan dalam memahami masalah-masalah Fisika yang sebelumnya sulit untuk dipahami menjadi lebih mudah (Alhidayatuddiniyah: 2021). Dalam mengatasi kesulitan peserta didik dalam pembelajaran Fisika dapat dilakukan dengan bantuan laboratorium virtual (Riantoni, Astalini, dan Darmaji, 2019). Laboratorium virtual terbukti memberikan efek yang positif terhadap perkembangan keterampilan peserta didik, sikap dan pemahaman konsep (Farrokhnia \& Esmailpour, 2010).

Dalam beberapa dekade terakhir ini telah banyak keyakinan tentang potensial dari realita virtual untuk menunjang belajar dan pembelajaran dalam laboratorium sains. Menurut Farrokhnia \& Esmailpour (2010) dalam kondisi yang tepat, simulasi dapat sangat efektif menggantikan peralatan laboratorium nyata. Salah satu laboratorium virtual yang banyak digunakan dalam pembelajaran Fisika di sekolah adalah simulasi interaktif PhET. Beberapa penelitian telah mengungkapkan efek positif dari penggunaan PhET dalam pembelajaran (Rizaldi, Jufri, \& Jamaluddin, 2020); Saputra, Nur, M., \& Purnomo, 2019).

Berangkat dari pemikiran di atas, artikel ini bermaksud untuk mengungkapkan bagaimana simulasi interaktif PhET digunakan dalam pembelajaran IPA pada topik Hukum Coulomb di Kelas IX semester ganjil tahun pelajaran 2021/2022.

\section{Metodologi}

Penulisan artikel ini menggunakan metode deskriptif kualitatif. Data yang digunakan diperoleh dari hasil penelitian berupa penyelidikan dan observasi kegiatan pembelajaran di dalam kelas. Penelitian penyelidikan dimaksudkan untuk memperoleh pengetahuan baru berdasarkan fakta-fakta yang ditemukan (Pandey \& Pandey, 2021). Adapun sampel dalam penulisan artikel ini adalah siswa kelas IX-A sebanyak 16 siswa. Tidak ada teknik khusus yang dipilih untuk menentukan sampel. Kelas yang dipilih sebagai sampel ditetapkan berdasarkan pelaksanaan jadwal mengajar pada saat topik Hukum Coulomb ini disampaikan. Pengumpulan data dalam penulisan artikel ini dilakukan melalui teknik observasi pembelajaran dan catatan refleksi para observer ketika kelas pembelajaran dilaksanakan. Pengumpulan data dilakukan dalam satu kali pertemuan, yaitu pertemuan kedua dari pembelajaran listrik statis.

\section{$3 \quad$ Hasil dan Pembahasan}

PhET Interactive Simulations merupakan sebuah proyek di Universitas Colorado yang mengembangkan sebuah alat simulasi yang difokuskan pada pembelajaran fisika, namun demikian PhET juga menyediakan beberapa simulasi untuk pembelajaran kimia, biologi, matematika dan sains lainya yang mendapatkan keuntungan dari penggunaan komputer sebagai alat bantu penggunaannya (Riantoni, Astalini, \& Darmaji: 2019)

Simulasi interaktif PhET pada artikel ini digunakan dalam pembelajaran pada topik Hukum Coulomb. Simulasi ini digunakan sebagai praktikum virtual untuk menemukan faktor-faktor yang mempengaruhi besar gaya Coulomb dari dua benda yang bermuatan. Dalam penggunaan simulasi interaktif PhET ini siswa bekerja dalam kelompok dan diberikan panduan praktikum berupa LKPD. Sebelum siswa melakukan praktikum, guru menjelaskan sekilas langkah kerja yang harus dilakukan siswa dalam menggunakan simulasi interaktif PhET untuk menemukan hubungan faktor-faktor yang mempengaruhi besar gaya Coulomb.

Langkah kerja percobaan secara lengkap dimuat dalam Lembar Kerja Peserta Didik (LKPD) yang diberikan kepada tiap kelompok siswa. Pada Kegiatan 1 LKPD Hukum Coulomb ini, simulasi interaktif PhET digunakan untuk: 1) menemukan hubungan besar dua muatan terhadap gaya Coulomb yang dihasilkan; 2) menemukan hubungan jarak kedua muatan terhadap gaya Coulomb yang terjadi. 


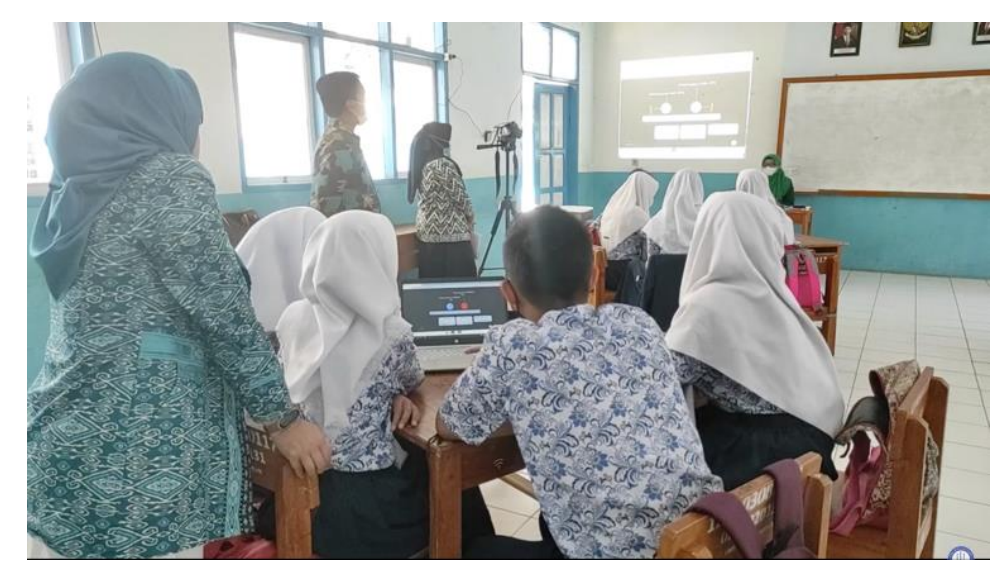

Gambar 1. Penjelasan singkat simulasi interaktif PhET yang digunakan untuk menemukan faktorfaktor yang memengaruhi besar gaya Coulomb.

Untuk menemukan hubungan muatan dan gaya Coulomb, siswa diminta mengisi 2 tabel yang disediakan. Pada Tabel 1.

Tabel 1. Hubungan muatan dan gaya Coulomb

\begin{tabular}{cccc}
\hline No. & Muatan $\mathbf{1}(\boldsymbol{\mu} \mathbf{C})$ & Muatan $2(\boldsymbol{\mu C})$ & $\begin{array}{c}\text { Gaya Coulomb yang } \\
\text { terjadi }(\mathbf{N})\end{array}$ \\
\hline 1 & -2 & 2 & \\
2 & -2 & 3 & \\
3 & -3 & 2 & \\
4 & 3 & 5 & \\
5 & -3 & 1 & \\
\hline
\end{tabular}

Hubungan muatan dan gaya Coulomb, disajikan 5 data tentang besar muatan $\left(\mathrm{Q}_{1}\right.$ dan $\left.\mathrm{Q}_{2}\right)$ dan siswa diminta mengisi kolom gaya Coulomb yang terjadi. Pada aktivitas ini, kegiatan siswa menggunakan simulasi interaktif PhET dengan menggerakkan kursor pada masing-masing muatan, kemudian mencatat besar gaya Coulomb yang terjadi yang ditunjukkan dalam simulasi interaktif PhET tersebut untuk setiap data percobaan yang disajikan. Untuk aktivitas ini, jarak kedua muatan dibuat tetap sebesar $2 \mathrm{~cm}$. Pada data 1 disajikan muatan 1 sebesar $-2 \mu \mathrm{C}$ dan muatan 2 sebesar $2 \mu \mathrm{C}$ sebagaimana ditunjukkan dalam gambar berikut.

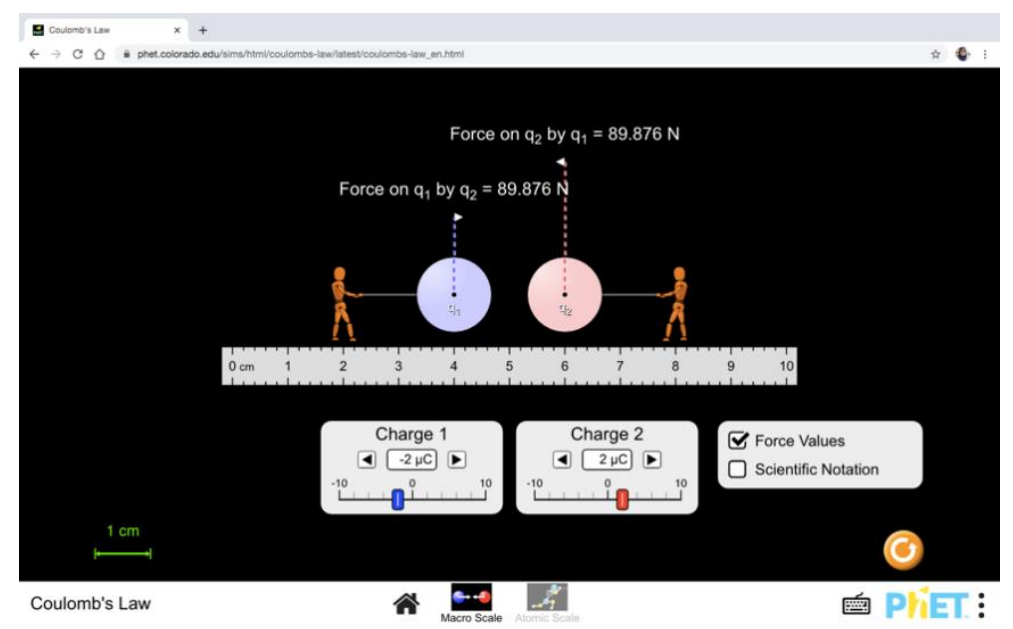


Gambar 2. Penggunaan simulasi interaktif untuk menemukan hubungan muatan dengan gaya Coulomb

Pada aktivitas menemukan hubungan besar muatan dan gaya Coulomb, siswa menggunakan simulasi interaktif PhET dengan menggerakkan kursor pada masing-masing muatan sesuai data percobaan yang disajikan dan menuliskan besar gaya Coulomb yang ditunjukkan dalam simulasi tersebut. Sementara jarak kedua muatan dibuat tetap. Setelah siswa melengkapi Tabel 1 dengan data yang diperoleh melalui simulasi interaktif PhET, siswa diminta menuliskan hasil pengamatannya dengan mengisi beberapa pertanyaan yang mengarahkan pada kesimpulan hubungan gaya Coulomb dengan muatan-muatan yang berinteraksi.

Sementara itu, untuk menemukan hubungan jarak kedua muatan terhadap gaya Coulomb yang terjadi, siswa diminta mengisi Tabel 2.

Tabel 2. Hubungan jarak dan gaya Coulomb

\begin{tabular}{ccc}
\hline No. & $\begin{array}{c}\text { Jarak antar muatan } \\
(\mathbf{c m})\end{array}$ & $\begin{array}{c}\text { Gaya Coulomb yang } \\
\text { terjadi }(\mathbf{N})\end{array}$ \\
\hline 1 & 10 & \\
2 & 8 & \\
3 & 5 & \\
4 & 4 & \\
5 & 2 & \\
\hline
\end{tabular}

Pada Tabel 2. Hubungan jarak dan gaya Coulomb, disajikan 5 data tentang jarak antar muatan dan siswa diminta mengisi kolom gaya Coulomb yang terjadi. Pada aktivitas ini, kegiatan siswa menggunakan simulasi interaktif PhET dengan menggerakkan kursor pada masing-masing simbol orang atau bola muatan, kemudian mencatat besar gaya Coulomb yang terjadi yang ditunjukkan dalam simulasi interaktif PhET tersebut untuk setiap data percobaan yang disajikan. Untuk aktivitas ini, besar kedua muatan dibuat tetap yakni masingmasing sebesar $-2 \mu \mathrm{C}$ dan $2 \mu \mathrm{C}$. Pada data 1 disajikan jarak antar muatan $10 \mathrm{~cm}$ sebagaimana ditunjukkan dalam gambar berikut.

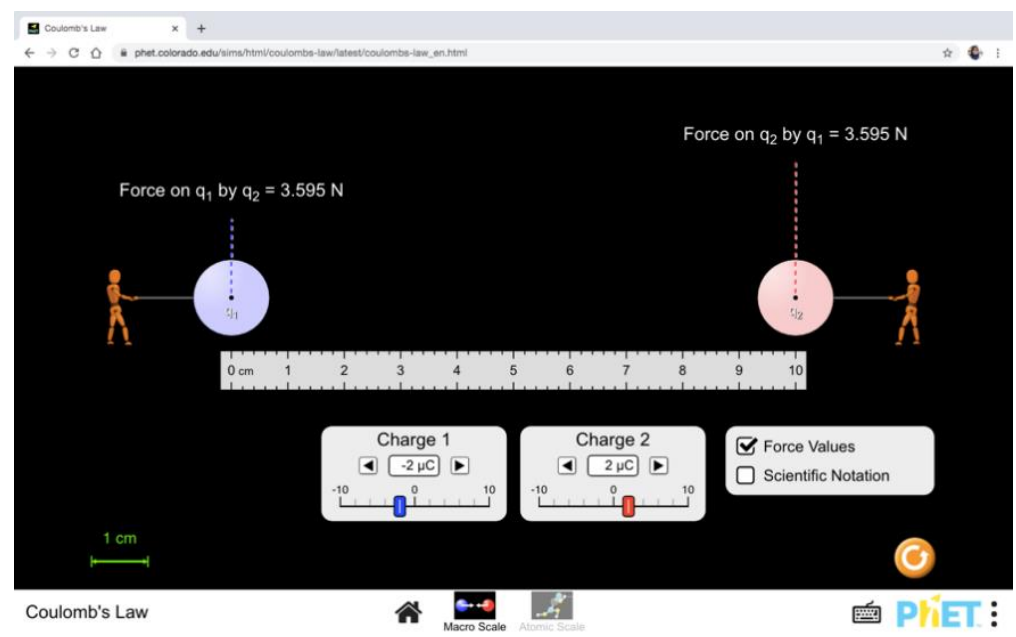

Gambar 3. Penggunaan simulasi interaktif untuk menemukan hubungan jarak antar muatan dengan gaya Coulomb

Untuk menyelidiki hubungan antara jarak antar muatan dengan besar gaya Coulomb, siswa mengubah jarak antar muatan pada simulasi PhET dan mengamati besar gaya yang timbul. Sementara besar kedua muatan dibuat tetap. Setelah siswa melengkapi Tabel 2 dengan data yang diperoleh melalui simulasi interaktif PhET, 
siswa diminta menuliskan hasil pengamatannya dengan mengisi beberapa pertanyaan yang mengarahkan pada kesimpulan hubungan gaya Coulomb dengan jarak antar muatan yang berinteraksi.

Berdasarkan hasil pengamatan yang diperoleh, siswa melakukan diskusi untuk menemukan hubungan antara besar gaya Coulomb dengan besar muatan dan jarak antar muatan. Respons yang diharapkan dari aktivitas ini, siswa mendapat kesimpulan sebagaimana yang disajikan dalam Gambar 4. Setelah siswa menyelidiki hubungan besar gaya dengan besar muatan dan jarak antar muatan, siswa kemudian menyimpulkan hubungan gaya Coulomb dengan kerangka berpikir seperti pada Gambar 5.

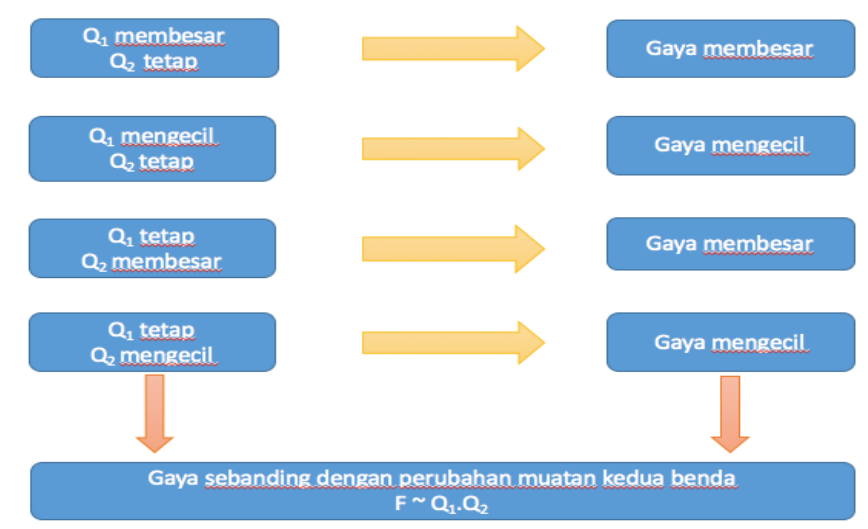

Gambar 4. Kesimpulan hubungan gaya Coulomb dengan besar masing-masing muatan

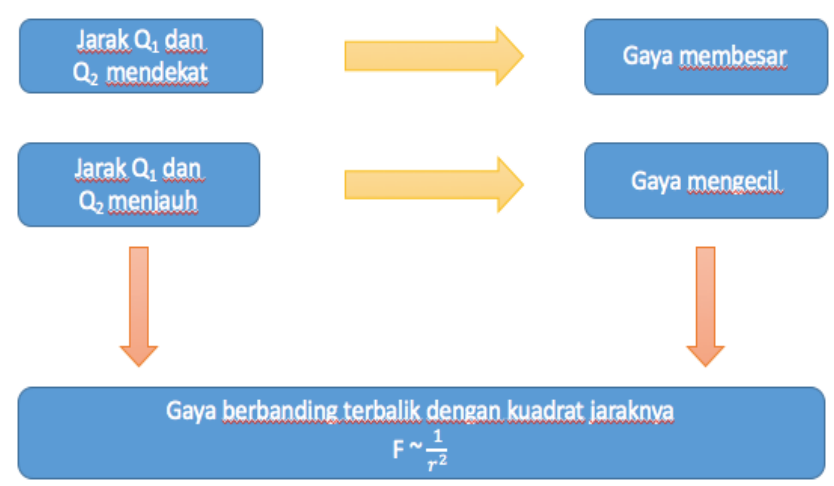

Gambar 5. Kesimpulan hubungan gaya Coulomb dengan jarak antar muatan

Setelah mendapatkan hubungan antara gaya Coulomb dengan besar masing-masing muatan dan jarak antar kedua muatan, secara klasikal siswa diarahkan menyimpulkan gaya Coulomb yang terjadi dan faktor-faktor yang mempengaruhinya yang kemudian dikenal sebagai Hukum Coulomb. Sebagai penguatan penerapan Hukum Coulomb ini siswa kemudian menyimak penerapan Hukum Coulomb dalam penyelesaian masalah berupa latihan soal beserta pembahasannya.

Berdasarkan data-data yang diperoleh dari hasil observasi dan catatan refleksi para observer diperoleh gambaran penggunaan simulasi interaktif $\mathrm{PhET}$ pada pembelajaran topik Hukum Coulomb sebagai berikut.

1. Penggunaan simulasi interaktif PhET membantu siswa menganalisis faktor-faktor yang mempengaruhi gaya Coulomb berdasarkan data praktikum yang diperoleh dengan lebih mudah. 
Hanya dengan menggeser kursor pada besar muatan-muatan yang disesuaikan dan jarak antar muatan yang dapat diatur dengan mudah, pada saat yang singkat siswa mendapatkan besar gaya Coulomb yang ditunjukkan oleh simulasi tersebut. Dengan menganalisis perubahan besar muatan, jarak antar muatan dan besar gaya Coulomb yang terjadi yang ditunjukkan melalui penggunaan simulasi interaktif PhET, siswa dapat menjelaskan bagaimana gaya Coulomb yang terjadi berdasarkan besar masing-masing muatan dan jarak antar muatan.

2. Penggunaan simulasi interaktif PhET membuat siswa antusias melakukan pembelajaran. Siswa terlihat lebih senang melakukan pembelajaran dengan praktikum walaupun secara virtual. Hal ini ditunjukkan dengan antusias setiap anggota kelompok untuk mencoba melakukan simulasi virtual tersebut bergantian dalam kelompoknya.

3. Dialog siswa dalam setiap kelompok berjalan interaktif. Kolaborasi siswa dalam kelompok juga baik. Ketika ada siswa yang belum mengerti dalam kelompoknya, siswa lainnya yang sudah mengerti akan membantu menjelaskan sampai siswa yang belum mengerti tersebut paham.

\section{Kesimpulan}

Berdasarkan paparan dan pembahasan yang telah diuraikan dapat disimpulkan bahwa simulasi interaktif PhET dapat digunakan sebagai pengganti laboratorium riil dalam topik Hukum Coulomb. Simulasi ini dapat membantu peserta didik dalam menemukan hubungan gaya Coulomb dengan faktor-faktor yang mempengaruhinya, dan membangun konsep Hukum Coulomb. Selain itu juga penggunaan simulasi interaktif PhET menunjukkan bahwa penggunaan PhET memberikan pengaruh positif pada antusiasme siswa dalam pembelajaran topik Hukum Coulomb dan kemampuan pemecahan masalah peserta didik, karena PhET dapat menjelaskan konsep yang abstrak dan dalam penggunaannya tidak memerlukan waktu yang banyak.

\section{Ucapan Terima Kasih}

Ucapan terima kasih dan penghargaan disampaikan penulis atas dukungan dari Direktorat Sumber Daya Kementerian Pendidikan Kebudayaan Riset dan Teknologi atas dukungan pembiayaan program serta Universitas Garut sebagai mitra pada Program Kemitraan Dosen LPTK dan Guru di Sekolah.

\section{Daftar Pustaka}

Alhidayatuddiniyah, T.W. (2021). Pengembangan Media Pembelajaran Berbasis Whiteboard Animation pada Pokok Bahasan Hukum Coulomb. Seminar Nasional Riset dan Teknologi (SEMNAS RISTEK)

Farrokhnia, M.R \& Esmailpour, A, A Study on The Impact of Real, Virtual and Comprehensive Experimentingon Students' Conceptual Understanding of DC Electric Circuits and Their Skills in Undergraduate Electricity Laboratory. Procedia Sosola and Behavioral Science, Vol 2, 2010, pp 5474-5482.

Pandey, P., \& Pandey, M. M. (2021). Research Methodology Tools and Techniques.

Riantoni, C., Astalini, A., \& Darmaji, D. (2019). Studi penggunaan PhET Interactive Simulations dalam pembelajaran fisika. Jurnal Riset dan Kajian Pendidikan Fisika, 6(2), 71-75.

Rizaldi, D. R., Jufri, A. W., \& Jamaluddin, J. (2020). PhET: SIMULASI INTERAKTIF DALAM PROSES PEMBELAJARAN FISIKA. Jurnal Ilmiah Profesi Pendidikan, 5(1), 10-14.

Saputra, T. B. R. E., Nur, M., \& Purnomo, T. (2019). Pengembangan Pembelajaran Inkuiri Berbantuan PhET untuk Melatihkan Keterampilan Proses Sains Siswa. Journal of Science Education And Practice, 1(1), 20-31.

Zubaidah, S.,dkk. (2018). Buku Guru Ilmu Pengetahuan Alam. Jakarta: Kementerian Pendidikan dan Kebudayaan. 